\title{
PEOPLE IN ORGANISATIONS
}




\title{
PEOPLE IN ORGANISATIONS
}

\author{
SECOND EDITION
}

\author{
Edward Sallis \\ and \\ Kate Sallis
}

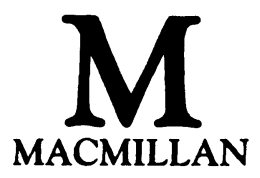


(C) Edward Sallis and Kate Sallis 1988, 1990

All rights reserved. No reproduction, copy or transmission of this publication may be made without written permission.

No paragraph of this publication may be reproduced, copied or transmitted save with written permission or in accordance with the provisions of the Copyright, Designs and Patents Act 1988 , or under the terms of any licence permitting limited copying issued by the Copyright Licensing Agency, 33-4 Alfred Place, London WC1E 7DP.

Any person who does any unauthorised act in relation to this publication may be liable to criminal prosecution and civil claims for damages.

First edition 1988

Second edition 1990

Published by

MACMILLAN EDUCATION LTD

Houndmills, Basingstoke, Hampshire RG21 2XS

and London

Companies and representatives

throughout the world

British Library Cataloguing in Publication Data

Sallis, Edward

People in organisations. -2 nd ed.

1. Organisations

I. Title II. Sallis, Kate

302.3'5

ISBN 978-0-333-52513-5

ISBN 978-1-349-11610-2 (eBook)

DOI 10.1007/978-1-349-11610-2 


\section{Contents}

Introduction to the Second Edition

\section{SECTION I: STUDY}

1 How to Study 3

Having a goal 3

Activity: 'What are your goals?' 4

Study - the preliminary steps 4

The diary method of learning $\quad 8$

Making effective notes $\quad 8$

2 Thinking and Creativity 12

Critical and creative thinking 13

Brainstorming 14

$\begin{array}{ll}\text { Key words } & 15\end{array}$

3 Managing your Time 17

Logging your time $\quad 18$

Activity: 'A time log' 20

Negotiation on work schedules $\quad 20$

Priorities and objectives $\quad 21$

$\begin{array}{ll}\text { Managing paperwork } & 21\end{array}$

\section{SECTION II: COMMUNICATION}

4 What is Communication? 25

Analysing communication - the theory 25

Communication barriers 28

Oral communications $\quad 29$

Qualities of speech 31 
Listening 33

Improving listening skills $\quad 34$

5 The Business Letter 36

What are business letters for? 37

Corporate identity and logos 37

Activity: 'Logos' 38

Statutory requirements 38

Other essential information and stationery style $\quad 39$

How to lay out a business letter 40

Writing the letter 46

Tone and style $\quad 48$

Standard letters and paragraphs $\quad 49$

Activity: 'Letter writing' 49

6 The Memorandum 51

The format of the memo 51

What are memos used for?

Style $\quad 53$

Activity: 'Writing memos'

7 Using the Telephone 56

Activity: 'Smiling voices' $\quad 57$

Receiving calls $\quad 57$

Making calls $\quad 58$

8 Report Writing $\quad 60$

Types of report $\quad 60$

$\begin{array}{ll}\text { Writing a report } & 61\end{array}$

Structure of reports $\quad 64$

Activity : 'Report writing' 65

9 Press Releases 66

Writing a press release $\quad 66$

Activity: 'Designing a press release' $\quad 68$

10 Visual Presentation of Information 69

$\begin{array}{ll}\text { Thinking in pictures } & 70\end{array}$

Varieties of presentation $\quad 71$

$\begin{array}{ll}\text { Bar charts } & 71\end{array}$

Line graphs $\quad 74$

Combined bar and line graph $\quad 77$

Pie charts $\quad 77$

Bubble charts $\quad 79$

Activity: 'Bubble chart analysis' $\quad 80$

Pictograms $\quad 80$ 
11 Giving a Talk $\quad 82$

Preparing for a talk $\quad 82$

Activity: 'A talk'

12 Non-Sexist and Non-Discriminatory Language 86

Activity: 'Alternative titles' $\quad 88$

How to avoid using sexist language $\quad 89$

Activity: 'Non-discriminatory language' $\quad 90$

\section{SECTION III: ORGANISATIONS}

13 The Structure of Organisations 93

How are organisations structured? $\quad 94$

Activity: 'An organisation chart' $\quad 94$

Activity: 'College structure' 98

Response to technological change - mechanistic and organic 99 structures

Answers to 'organisation chart' activity 100

$\begin{array}{ll}\text { Organisation design } & 100\end{array}$

$\begin{array}{ll}\text { Formal and informal organisations } & 101\end{array}$

14 Organisational Concepts 105

$\begin{array}{ll}\text { Accountability } & 105\end{array}$

Activity: 'Accountability' 107

$\begin{array}{ll}\text { Authority } & 108\end{array}$

Activity: 'Sources of authority' 108

$\begin{array}{lr}\text { Bureaucracy } & 109\end{array}$

Delegation $\quad 109$

Excellence $\quad 109$

Hierarchies $\quad 110$

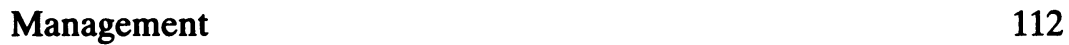

$\begin{array}{lr}\text { Power } & 113\end{array}$

Responsibility 115

Span of control $\quad 115$

Staff and line $\quad 116$

Activity: 'College organisation chart' 117

$\begin{array}{ll}\text { Status } & 117\end{array}$

Answers to the 'Sources of authority' activity 118

15 Meetings 119

Types of meetings $\quad 120$

Committee meetings 121

The 'hidden agenda' 123

Taking minutes 125

How to be successful at meetings 125 
16 Information and Information Systems 127

Levels of information 128

Too much information $\quad 129$

$\begin{array}{lr}\text { Filing systems } & 129\end{array}$

Information sources 131

Computers in business 133

The impact of information technology 134

The language of computing 134

Some computer essentials $\quad 135$

Activity: 'Word processing' 142

17 Management Services 145

Methods of change $\quad 145$

Managing by objectives $\quad 145$

$\begin{array}{ll}\text { Organisation and Methods } & 147\end{array}$

How $\mathrm{O} \& \mathrm{M}$ is carried out $\quad 148$

18 Job Evaluation 152

Why should some jobs be worth more than others? 152

Activity: 'Job evaluation' 153

Methods of job evaluation 155

Job ranking 156

Activity: 'Job ranking' 156

Paired comparisons $\quad 157$

Analytical methods 157

Job evaluation procedure under points rating 159

$\begin{array}{ll}\text { Criticisms of job evaluation } & 160\end{array}$

\section{SECTION IV: PEOPLE}

19 Groups 165

What is a group? 165

Activity: 'Group membership' 167

Formal and informal groups 167

What are groups good at? 167

Group norms $\quad 168$

$\begin{array}{ll}\text { Stages of group development } & 169\end{array}$

Features of an effective work group $\quad 170$

Behaviour in groups $\quad 171$

$\begin{array}{ll}\text { Group roles } & 172\end{array}$

Interactions in groups $\quad 174$

$\begin{array}{ll}\text { Quality circles } & 176\end{array}$

Activity: 'Analysing a work group' 177 
20 Leadership 179

$\begin{array}{ll}\text { What is a leader? } & 179\end{array}$

Leadership traits $\quad 180$

Activity: 'Leadership qualities' 180

Styles of leadership and management 181

21 Self-presentation 183

Roles $\quad 184$

How should I get my message across?

Yourself and others $\quad 186$

Being assertive 188

$\begin{array}{ll}\text { Structuring arguments and persuading others } & 189\end{array}$

22 Motivation and Human Needs 193

What is motivation? 194

Human needs 194

Activity: 'Motivation - a self-analysis' 194

Personnel policy and human needs 196

Is money a motivator? 198

The hygiene/motivator theory 199

What should an interesting job contain? 200

Activity: 'Your own motivation' 201

Equity theory 201

Activity: 'Equity and motivation' 202

Expectations and motivation 202

Job satisfaction 203

23 The Employment Process 205

The selection process - the employer's needs 205

Employee specification 206

Activity: 'Describe yourself - a self-appraisal exercise' 206

Human resource planning 207

Aptitude and psychometric tests 211

24 Job Hunting 213

Where to look for a job 213

Application forms and CVs 214

Activity: 'Analysis of Sheila's CV' 218

Activity: 'Letter of application' 222

25 Interviews 224

Preparing for an interview 224

Types of interview $\quad 227$

Interview questions $\quad 229$ 
26 Performance Appraisal

Does every organisation have a form of staff appraisal? 232

The purpose of appraisal 233

Appraisal methods 235

Self-appraisal $\quad 237$

An appraisal interview checklist 237

Activity: 'Preparing for the annual appraisal interview' 239

27 Opportunities and Change 240

What business am I in? $\quad 240$

Activity: 'Opportunities' 242

The problem of change $\quad 242$

How to recognise opportunities 243

SWOT 243

Activity: 'New ideas' 245

Career planning 245

Activity: 'Career planning' 247

\section{SECTION V: ASSIGNMENTS}

1 Mapping the College's Structure 251

2 The Press Release 253

3 Applying for a Job 255

4 Facing up to Change 258

5 Systems Analysis 255

$\begin{array}{ll}\text { Bibliography } & 263\end{array}$

$\begin{array}{ll}\text { Index } & 266\end{array}$ 


\section{Introduction to the Second Edition}

People in Organisations is the theme as well as the title of this book. It has been written mainly for students studying for BTEC National Awards in Business and Finance, Distribution, Public Administration, Leisure Studies and Travel and Tourism. However, we feel that it will be of benefit to others wishing to know about the human aspects of the world of work including those studying for BTEC Higher Awards.

In this second edition we explore the major activities which people do at work and the important influences on them. The book provides answers to a range of questions examples of which are:

'How can you become a better communicator?'

'What type of language is most appropriate in various business situations?'

'What motivates you to do a good job?'

'How do you know if you are successful?'

'How will information technology shape your life?'

'How can I make better use of my time?'

'Are there better ways of studying?'

'How can I become more effective at work?'

'How can I improve my job-seeking skills and career planning?'

'Am I sufficiently aware of the needs of others?'

'What makes a good leader?'

'How can I perform better at interviews?'

In short, this book will help you to be a more effective member of an organisation. It is not all you will need. We do not claim a comprehensive coverage of every aspect of the syllabus. No textbook can do justice to every aspect of a BTEC syllabus. This book is one of the many aids to learning and is only a part of your total educational experience. Your 
lecturers' notes and the assignments you will be given are important complementary activities to the book.

You will already have some experience of organisations. You may be in employment full-time, on youth training, or studying full-time at a Further Education college. You will probably have had periods of work experience or part-time jobs. You will be a member of clubs, societies, voluntary bodies or other organisations. Your experience of these organisations can provide you with insights into how they work. You should relate the material on your course and in this book to these experiences. Many of the assignments you complete during your course will help you to do just that. In addition, during your period of study you will visit offices and factories and, of course, you go shopping and visit places like leisure centres, concert halls, theatres and swimming pools. How often have you been into a shop and thought 'this place is inefficient' or 'this is my favourite shop - the assistants are always knowledgeable and friendly', or again 'they really ought to improve the layout here - you cannot find a thing'? All of these are organisational judgements. Most of us stop here and rarely ask the more searching questions. What makes this shop better than that one? Why is this sports centre well organised and attractive?

You need a knowledge of organisational theory and some of the fundamentals of social psychology before you can ask penetrating questions about organisations. You also need to know how organisations communicate with their employees, customers and clients. Sections II, III and IV will provide you with these insights.

This book is concerned with PEOPLE and in particular YOU. It is a well-worn cliche that an organisation is only as good as the people working in it, but it is nevertheless true. You will want to know how best to prepare yourself for working life, how to relate to others and what an organisation expects of you.

The authors have taught BTEC students at First, National, Higher National and Continuing Education levels and as a result we know the demanding yet fascinating time BTEC students can have on their courses. We are committed to a student-centred approach to learning and we believe that you learn best by taking part in activities. To promote this approach we have included a number of activities in the book which are designed to help you to develop your skills.

The subject is a fascinating one and the rewards are great. We wish you every success with your study. 


\section{Acknowledgements}

Extracts from BSA A1001 and BS 3138: 1979 on pages 147 and 152 are reproduced by permission of BSI. Complete copies can be obtained from them at Linford Wood, Milton Keynes, MK14 6LE.

The quoted material on pages $160-1$ is reproduced with the permission of The Times Educational Supplement. 